\title{
Implementation of QRIS-Based Payments Towards the Digitalization of Indonesian MSMEs
}

\author{
Arum Candra Sari \\ IAIN Pekalongan, Indonesia \\ @ mbs.iainpekalongan.aci.id
}

\section{Hendri Hermawan Adinugraha}

IAIN Pekalongan, Indonesia

bendri.hermawan@iainpekalongan.ac.id

\begin{tabular}{|l|l|l|}
\hline Submitted: 2021-11-22 & Revised: 2021-12-27 & Published: 2021-12-31 \\
\hline
\end{tabular}

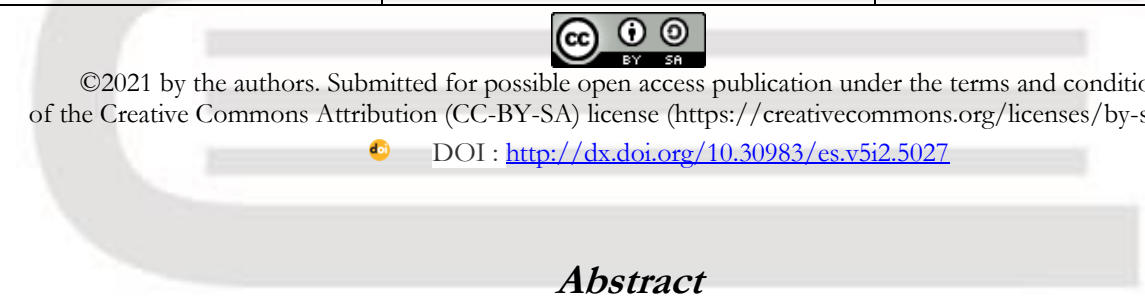

This study aims to determine the implementation of QRIS as measured by the existence and urgency as a payment digitalization medium to support the Digitalization of MSMEs in the context of Indonesia's economic recovery. This research is a literature study that was analyzed using a qualitative-descriptive approach with secondary data sources originating from journals and reports related to the Digitalization of MSMEs. The results and discussion of this research, that the QRIS launched by Bank Indonesia can help MSME actors adapt to existing conditions. QRIS as a MSME survival strategy is carried with the theme EXCELLENCE (UNiversal, Easy, Profit and Direct). The theme was taken because the use of QRIS is easy and practical, namely by scanning the QR code that has been provided by the merchant. QRIS has been officially launched and supervised under Bank. Indonesia. The easy use of QRIS provides benefits for both merchants and buyers, especially for users of non-cash payment applications. For merchants, QRIS is useful in terms of increasing sales, practicality, branding, saving, avoiding counterfeit money, segregating business funds, and credit profiles. QRIS are flexible, safe and practical so that QRIS can become the driving force in the acceleration of digitalization for economic recovery.

Keywords: MSMEs, Digitalization, QRIS.

Abstrak

Penelitian bertujuan untuk mengetahui implementasi dari QRIS yang diukur dari eksistensi serta urgensi sebagai media digitalisasi pembayaran guna mendukung digitalisasi UMKM dalam rangka pemulihan perekonomian Indonesia. Penelitian ini merupakan penelitian studi pustaka yang dianalisis dengan menggunakan pendekatan kualitatif-deskriptif dalam menjelaskan fenomena terkait implementasi QRIS pada UMKM. Sumber data yang digunakan adalah sumber data sekunder yang berasal dari jurnal maupun laporan terkait dengan digitalisasi UMKM. Hasil dan pembahasan dari penelitian ini, bahwa QRIS yang diluncurkan oleh Bank Indonesia dapat membantu adaptasi pelaku UMKM terkait kondisi yang ada. QRIS sebagai strategi bertahan UMKM ini diusung dengan tema UNGGUL (UNiversal, GampanG, Untung dan Langsung). Tema tersebut diambil karena penggunaan QRIS yang mudah dan praktis, yaitu dengan melakukan scan pada QR code yang sudah disediakan oleh merchant. QRIS telah resmi diluncurkan dan diawasi dibawah Bank Indonesia. Penggunaan QRIS yang mudah memberikan manfaat baik bagi merchant maupun kepada pembeli terutama bagi pengguna aplikasi pembayaran non tunai. Bagi merchant, QRIS bermanfaat dalam segi, peningkatan penjuala, praktis, branding, hemat, penghindaran uang palsu, pemisahan dana usaha, dan credit profile. Bagi pengguna, manfaat QRIS berupa, fleksibel, aman dan praktis. Dalam hal ini, maka dapat dikatakan QRIS sebagai pendorong percepatan digitalisasi guna pemulihan ekonomi.

Kata Kunci: UMKM, Digitalisasi, QRIS. 


\section{Background}

The Covid-19 pandemic that occurred in 2019 has become the biggest challenge for every country in the world. The pandemic caused by the corona virus has hit various aspects of life, starting from the economy, finance, socio-culture, industry and several other aspects. The current COVID-19 pandemic has shaken all aspects of life. Based on data from WHO, in June 2020, there were $8,242,999$ cases recorded with a death rate of 445,535 , where this number tends to increase every day. ${ }^{1}$

Indonesia is one of the countries that has been affected by the COVID-19 pandemic. The impact of the pandemic, especially in economic growth in Indonesia, experienced a drastic decline in the first quarter of 2020. This decline in economic growth was not only caused by the spread of the corona virus but also due to various policies to handle the corona virus by the government. ${ }^{2}$ The data on the economic downturn can be seen in the following graph.

Figure 1. Indonesia's Economic Growth Chart

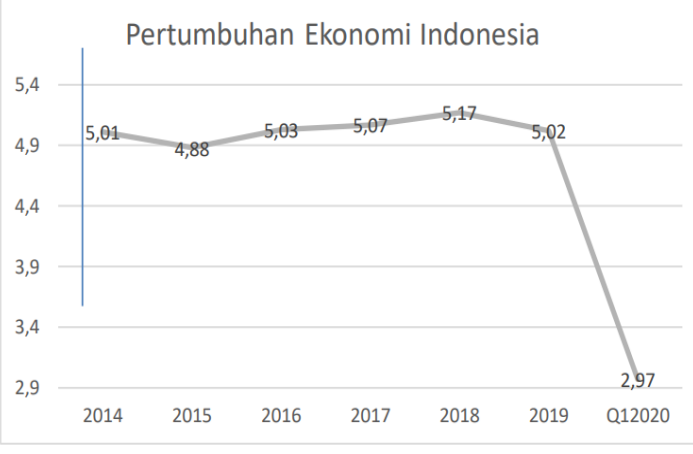

(Source: BPS data 2020)

Based on the graph above, it can be concluded that in the first quarter of 2020, there was a decline in the economy. In that year, economic growth in Indonesia only reached $2.97 \%$, which is lower than Bank Indonesia's projection of $4.4 \%$.

Responding to the negative impact of this pandemic, the government is pursuing several policies for economic recovery. These policies are like lockdown and New Normal. The implementation of the lockdown is in the form of reducing people's activities outside the home and closing several accesses in and out, which causes people to remain at home in carrying out their daily lives. After the lockdown, the government implemented the New Normal rule, in which the public can carry out their activities as usual, but must still comply with the health protocol in the form of $3 \mathrm{M}$ which consists of wearing masks, keeping a distance and staying away from crowds. However, it seems that the government and the public will have to be patient about this new policy. The implementation of these policies does not necessarily restore the economy quickly. This matter, there is still the proliferation of the Corona virus around the community, and there are still restrictions on community activities. (prasetyandari, 2021)

Micro Small Medium Enterprises (MSME) is one aspect that is an important concern in the economic downturn. The decline in MSMEs was due to the pandemic 
and several policies implemented in Indonesia. MSMEs play an important role in the economic ecosystem in Indonesia. Based on data from the website of the Coordinating Ministry for Economic Affairs of the Republic of Indonesia, the contribution of MSMEs to GDP reached $61.07 \%$ with the current number of MSMEs reaching 64.2 million. Realistically, MSMEs occupy an important and strategic position in the national economy. In addition, MSMEs absorb a large enough workforce, so that it can be said to be the economic foundation of the general public. ${ }^{3}$

As the impact of the pandemic, many MSME actors have to stop their activities. Based on data obtained, as of April 17, 2020, around $50 \%$ of the total number of MSMEs in Indonesia, around 64.2 million, were forced to close temporarily ${ }^{4}$. This is due to the sudden and continuous pandemic, making their business unable to survive. In this case, MSME actors are still not able to adapt to the phenomena and problems that occur. This condition is exacerbated by the ongoing pandemic. This causes not a few MSME actors who are not ready to face this.

In this regard, the government is trying to recover the Indonesian economy by making several policy strategies. As a form of effort to restore the existing economy, the government has formulated three types of policy strategies that can be carried out, namely short-term, medium-term and long-term policies. Shortterm policies focus on the health sector and welfare assistance for affected communities. The medium-term policy is to ensure the reoperation of the business world as well as the

\footnotetext{
${ }^{3}$ Retno Karunia Putri and others, 'Phk Rate Against Decline', 1.1 (2020), 50-55.

4 Moh. Musfiq Arifqi, 'Recovery of the Indonesian Economy Through Digitalization of ShariaBased MSMEs During the Covid-19 Pandemic', AlKharaj: Islamic Journal of Economics, Finance \& Business, $\quad 3.2 \quad$ (2021), 192-205 <https://doi.org/10.47467 /alkharaj.v3i2.311>.
}

continuity of the logistics sector and the independence of the health industry. Meanwhile, in the long term, the government intends to apply digitalization to MSMEs as a form of preparation for entering the industrial era. ${ }^{5}$

One of the policies that will be discussed is regarding the digitization of MSMEs. The existence of digitalization for MSMEs can make MSME actors know the "New Face of the World Economy", because in their activities, MSMEs are emphasized to utilize technology as much as possible. This can later be used as a provision in facing the progress of the times. Regarding digitalization, according to Muhammad Alfarizi et al, it was stated at this time that Bank Indonesia had predicted the rapid development of this digitalization trend. In this regard, Bank Indonesia seeks to accelerate digitalization in order to create an efficient and exclusive digital economic and financial ecosystem. ${ }^{6}$

One form of digitalization for MSMEs that is currently being developed is digitalization of payment. Digitalization of payments is meant by using the QR Code which was recently launched by Bank Indonesia. The QR Code in question is called QRIS. QRIS was launched by Bank Indonesia with the aim of facilitating transactions within MSMEs. Based on the journal from Oktoviana Banda Saputri, transactions with QRIS are carried out by the seller providing a QR Code which will then be scanned by the buyer. This process only takes a few moments. After that the payment process is complete. This QR

5 Siti Nuzul Laila Nalini, 'The Impact of Covid-19 on Micro, Small and Medium Enterprises', Jesya (Journal of Sharia Economics \& Economics), 4.1 (2021), 662-69 <https://doi.org/10.36778/jesya. v4i1.278>.

6 Muhammad Alfarizi, Rastinia Kamila Hanum, and Syaibatul Aslamiyah Hidayat, 'Optimizing the Use of Sharia Digital Transactions To Sup- Port Indonesia' S Economic Recovery', 6.1 (2021), 122-32 <https://doi.org/10.20473/ jiet.v6.i1.25977>. 
Code can be found in various existing digital wallet applications.

Based on this explanation, it can be said that transactions with QRIS are safe and easy. Then, in terms of sharia, transactions with QRIS can be said to be halal in Islam, because they do not contain elements of usury and interest. This is in accordance with the word of Allah SWT. in the Qur'an Surah AnNisa verse 29, which reads:

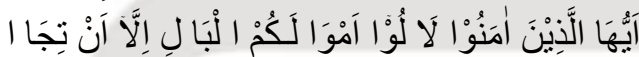

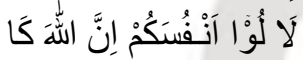

"Hei you who believe! Do not eat each other's property in a false way (not true), except in trade which is carried out on the basis of consensual between you. And don't kill yourself. Indeed, Allah is Most Merciful to you." (An-Nisa [5]: 29)

The importance of digitalization is certainly a concern for MSME actors, especially in terms of adapting to the phenomena that have occurred recently. But in reality, this digitization has not been implemented in a number of MSMEs, because MSMEs still do not fully understand the meaning of digitization. This makes it difficult for MSME actors and they prefer to continue using the manual method. This is in line with the research conducted by Taufiq Andre Setiyono, who in his research found that there are still many people who do not know what digitization is, especially in digitizing payments. In this study, the object studied was QRIS, where more than $550 \%$ of research respondents did not know about QRIS. ${ }^{8}$ Another research came from Yudistira Andi

Oktoviana Banda Saputri, 'Consumer Preferences in Using the Quick Response Code Indonesia Standard (QRIS) as a Digital Payment Tool', Journals of Economics and Business Mulawarman, 17.2 (2020), 237-47.

8 Taufiq Andre Setiyono, 'Indonesian's Acceptance of Non-Cash Transactions Using Qris', Proceedings of the 3rd International Conference on Banking, Accounting, Management and Economics (ICOBAME 2020), 169.Icobame 2020 (2021), 141-44 <https:/ /doi.org/10.2991/aebmr.k.210311.027>.
Permadi and Angestika Wilandari, where this research was conducted among students who have digital wallets. The results of this research that even though respondents have applications or facilities to use QRIS, they cannot use it due to lack of education related to QRIS.?

Regarding the analysis of the application of QRIS in this transaction, several researchers have previously done this. First, research conducted by Josef Ivan Sihaloho, Atilah Ramadani and Suci Rahmayanti relating to the implementation of the use of the Quick Response Indonesia Standard on SMEs in Medan, which in this study resulted that SMEs in Medan have switched to using non-cash payments via QR Code, which QR code that is often used is QR Code OVO ${ }^{10}$.

Further research was carried out by Ricky Akbar et al, regarding the design of a non-cash payment application in the Oto Pro Car Wash \& Detailing Padang car wash business based on QR Code technology. This research has resulted in the conclusion that to facilitate the transaction process both in terms of employees and customers, a QR Code is made specifically for payments. So there is no need to enter data manually, so it is hoped that this form of payment can overcome the problems that exist in that place. ${ }^{11}$

Subsequent research by Dwiny Indah Nastiti, Sitti Nur Azmi Fadhlurrahmah and Nurul Hermina, where the research conducted was related to the impact of using QRIS as a

${ }^{9}$ Yudistira Andi Permadi and Angestika Wilandari, 'Preferences of Using Quick Response Code Indonesian Standard (QRIS) Among Students as a Means of Digital Payment', 03.01 (2021).

10 Journal of Business Management, '(1)(2)(3)', 17.2 (2020), 287-97.

11 Ricky Akbar, Meza Silvana, and Fikiri Aulia Alizar, 'Design of a Non-Cash Payment Application for Car Wash Business Management Using QR Code Technology (Case Study: Oto Pro Car Wash \& Detailing Padang)', National Seminar on Science and Technology, $1.1 \quad$ (2019 ), 1-13 <jurnal.umj.ac.id/index.php/semnastek>. 
digital payment method. ${ }^{12}$ The impact in question is viewed from the macroenvironmental impact and consumer behavior through work programs. The result of this research is that the marketing carried out by MSEs in West Java uses QRIS as the medium. Where in this case that the increase in marketing carried out can improve the performance of SMEs in West Java ${ }^{13}$. From the three studies, it can be concluded that in some regions in Indonesia, QRIS has been used in its payments. In addition, the use of QRIS has a positive impact on the survival of the MSMEs. The positive sustainability of MSMEs can have a positive impact on the country's economy.

Indonesia, precisely in 2021, is entering the industrial 5.0 period, which is marked by the rapid development of Science and Technology. The rapid development of science and technology has changed the condition of Indonesia in various aspects, especially the economic aspect. The industrial revolution has formed a new economic ecosystem called the digital economy ecosystem. This situation was then supported by a series of policies implemented by the government, for example, Work From Home (WFH) and the Implementation of Large-Scale Restrictions (PSBB). Facing such conditions, as the main key in the economy, MSME actors are required to be able to adapt, so that their business can survive. One form of digitalization adaptation

12 Rizkyka Choirunnisa and Egi Arvian Firmansyah, 'Muslim Consumer Behavior and Purchase', EKONOMIKA SYARIAH: Journal of Economic Studies, 5.1 (2021), 11-30.

13 Dwiny Indah Nastiti and others, 'the Impacts Of Macro Environment And Consumer Behavior On Performance Improvement Through Marketing Program ( Case Study On The Use Of Digital Payment System Qris By Smes In West Java, Indonesia ), 89 32.3-(2021 )', 89 32.3-2083 . that can be done by carrying out non-cash payments is using the QRIS media. ${ }^{14}$

\section{Problems and Goals}

Based on the background described previously, the problems raised in this study consist of three things, namely, first, the problem of analyzing the development of MSMEs in Indonesia, second, regarding the digitalization of QRIS-based payments for MSMEs, third, regarding the urgency of QRIS in realizing digitalization of payments for MSMEs. These three problems are used as the basis for discussion regarding the digitization of MSMEs to support economic recovery in Indonesia.

Based on the explanation of the problem, the objectives of this research are formulated in the following three categories, namely, first, an explanation of the development of MSMEs in Indonesia. In this sub-chapter, we will describe the growth of MSMEs and their current development, followed by an analysis of their influence factors, second, regarding the existence of QRIS-based payment Digitalization for MSMEs. In this second sub-chapter, it will be explained about the existence of Digitalization which will then be devoted to QRIS, third, an explanation of the urgency of QRIS in realizing payment Digitalization for MSMEs. This subchapter explains the importance of having QRIS based on the impacts and benefits provided.

Through these three sub-chapters, it is hoped that they can provide understanding and knowledge to MSMEs in Indonesia to quickly adapt and start digital transformation, which can be started by changing the way they transact through QRIS. With this, MSMEs in

${ }^{14}$ Selena Riri Blandina, Alvin Noor Fitrian, and Wulan Septiyani, 'Strategies to Avoid Indonesia from the Threat of an Economic Recession During a Pandemic', Effector, 7.2 (2020), 181-90. 
Indonesia can play an active role in Indonesia's economic recovery.

\section{Framework of Thinking}

MSMEs are a pillar of the Indonesian economy. MSMEs play an important role in the recovery of the Indonesian economy. As of 2021, MSMEs will make several contributions, such as increasing the country's per capita income to providing job opportunities. Today, the number of MSMEs has increased significantly. This increase provides an opportunity for Indonesia's economic recovery in the midst of the pandemic. The increase in the number of MSMEs, of course, must be balanced with several series of efforts and assistance as a form of MSME's survival strategy. Based on this, the Indonesian government issued several short, medium and long term policies in order to prosper MSMEs in Indonesia. One form of existing policy is the Digitalization of MSMEs.

The Digitalization of MSMEs is a transformation carried out by MSMEs from being traditional to digital by making maximum use of existing technology. One of the Digitalization of MSMEs launched by the government and the Central Bank is the Digitalization of QR Code-based payments, which is named QRIS.

QRIS is a digital payment standard in the form of a QR Code that can be used in all existing PJSPs. QRIS, which is carried out by the Central Bank, is expected to provide convenience in the payment process for MSMEs and can provide opportunities for MSME adaptation in the current industrial era.

Figure 4. Research Thinking Framework

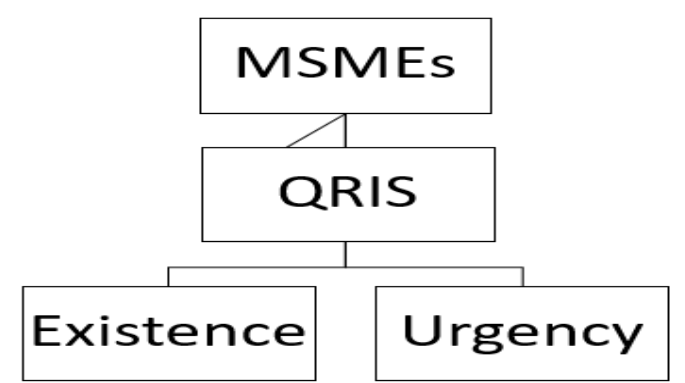

The focus in this research is the analysis of the implementation of the use of QRIS as a form of digitizing MSMEs in Batang District. The implementation analysis carried out will be supported by an analysis of the existence and impact of the use of QRIS by MSMEs in Batang District.

\section{Research Methodology}

This research is a research using a literature study approach, where data searches are carried out indirectly, namely through literature sources such as books, journals, reports and so on, related to the digitization of MSMEs in Indonesia which is devoted to the digitization of QRIS-based payments. When viewed based on the type of information, this research is a qualitative research, where the aim is to find out more about a phenomenon or event that is currently happening. The phenomenon in question is the application of digitalization of QRIS-based payments to MSMEs. The data used in this study is secondary data obtained from various literature sources related to the digitization of MSMEs in Indonesia

\section{Theoretical Framework MSMEs (MSMEs)}

MSMEs, by definition, are businesses that are run individually with a limited workforce and turnover. Based on the Law of the Republic of Indonesia No. 20 of 2008 concerning UMKM Article 1, microenterprises are productive businesses owned by individuals and/or individual business entities with micro-business criteria as stipulated in the Act. In Article 6, the criteria 
used in defining MSMEs are in the form of net worth or assets excluding land and buildings, place of business or annual sales proceeds with the following criteria. ${ }^{15}$

First, micro-enterprises are businesses whose assets excluding land and buildings are more than Rp. 50 million with maximum annual sales of Rp. 300 million. Second, the business ranges between Rp. 50 million to Rp. 500 million. Then, the sales results ranged from Rp. 300 million to Rp. 2.5 billion. Third, Medium enterprises, are business units with a net worth of up to Rp. 500 million to Rp. 10 billion, and annual sales of 2.5 billion to $\mathrm{Rp}$. 500 billion.

MSMEs in Indonesia are growing rapidly. The rapid development of MSMEs in Indonesia has a positive impact on the Indonesian economy. Based on the positive impact of MSMEs and their considerable role in the economy, the development of MSMEs requires a practical and systematic strategy. According to Agustinus et al, several efforts to increase MSMEs can be carried out such as improving the quality of products and consumer services, where this can be done individually or in groups. In addition, it is necessary to use technology in its business, such as in the distribution, marketing, market and so on which can have a positive impact on MSMEs themselves. ${ }^{16}$

\section{Digitalization}

The pandemic that occurred at the end of 2019 had a major impact on human

15 Suryati Eko Putro and Novie Noordiana, 'Development of Micro, Small and Medium Enterprises (MSMEs) in the Context of Economic Empowerment in the New Normal Era', Journal of Community Service, 1.2 (2021), 65-72.

${ }^{16}$ Agustinus Purna Irawan and others, 'The Role of Higher Education in Improving Micro, Small, and Medium Enterprises' Performance; A Case Study: Untar Untuk UMKM ', Proceedings of the International Conference on Economics, Business, Social, and Humanities (ICEBSH 2021), 570.ICEBSH (2021), 1417-20 <https://doi.org/10.2991/assehr.k.210805.222>. life. According to Adi Prehanto, the occurrence of a pandemic requires humans to think and adapt to the problems that arise during this pandemic. During the pandemic, the space for movement or activity mobility is limited, so at this time there will of course be changes in lifestyle. From the beginning, all activities were carried out directly or face-toface, now all activities carried out must be limited by reason of maintaining distance and even recommended to be done virtually. ${ }^{17}$.

The occurrence of the pandemic coincided with the industrial revolution 4.0, where in this realm there was a rapid development of science and technology. The Brantasari Court, explained that at this time humans were entering the period of globalization 4.0. a period where all human activities are carried out by utilizing technology, so that this facilitates human work. Technology is designed in such a way as to replace and drive physical and non-physical humans in carrying out their activities (Brantasari, 2021). Based on this explanation, it can be said that at this time, humans and technology are difficult to separate.

Based on this, the most appropriate adaptation to do during a pandemic is to take full advantage of existing technological developments and transform traditional habits into modern ones. In this case, it is known as Digitization. The digital era that occurs is integration between computer technology and internet technology, so that in this era, apart from rapid technological developments, there is also an increase in internet connectivity. Because of this, Caterin M. Simamora,

${ }^{17}$ Adi Prehanto, Rangga Gelar Guntara, and Nuraly Masum Aprily, 'Pemanfaatan Webinar Sebagai Alternatif Digitalisasi Informasi Dalam Seminar Kurikulum', Indonesian Journal of Digital Business, $1.1 \mathrm{Mei}$ 2021 (2021), 42-48. 
mentions some of the effects of the internet in daily work as follows: ${ }^{18}$

New jobs. The emergence of the internet and technology that is so rapid, will provide a new job field related to this, such as network specialists, hardware technicians and others.

Transformed jobs. The work is carried out by utilizing existing technology, but still with skilled human resources. The use of this technology will create efficiency, minimize errors, reduce time and costs, and increase product accuracy and quality.

Technology is changing work practices. In this case, the work process can be adapted to existing technological developments. in addition, the internet allows outsourcing of different parts of the production process.

Outsourcing. With the advent of technology and the internet, it is possible to move jobs to more specialized locations and workers.

Lost jobs. Advances in technology and the internet can trigger job losses, because in this case, technology takes over the job.

Basically, digitalization is expected to provide automation in human work, so that in this case there will be efficiency and effectiveness in carrying out their activities. This is in line with Shinta Maharani's statement, that there is digitalization where this will affect changes in human life, where she focuses on the economy here. That the existence of digitalization will bring the economic life of the community from what was originally a conventional manual to a modern one, wherein this case he also hopes that this digitalization can increase the

${ }^{18}$ Caterin Magdalena Simamora and Rahayu Ningsih, 'Inklusivitas Ekonomi Digital Di Indonesia: Perspektif Gender Dan Penciptaan Lapangan Kerja.', Cendekia Niaga, $4.2 \quad$ (2020), 39-53 <https://doi.org/10.52391/jcn.v4i2.507>. economic growth sector, especially the Islamic economy in Indonesian society. ${ }^{19}$

\section{QRIS}

QRIS or QR Code Indonesian Standard is a QR standard for digital national payments. QRIS launched by Bank Indonesia together with the Association and Industry is also a form of digitizing MSMEs in terms of payments. The digitization of MSMEs is carried out in the context of economic recovery due to the impact of the pandemic. QRIS itself is the unification of various QR codes from various PJSPs that use QR codes. The QR code according to Evelyn Angelita, based on the Regulation of the Members of the Board of Governors Number 21/18/PADG/2019 concerning the Implementation of the National Standard Payment for Quick Response Code Article 1 number 4 , is a two-dimensional code in which there is a marker without a square pattern in the lower-left corner, top left and top right, and there is a black square module in the form of dots or pixels. ${ }^{20}$ The launch of QRIS by Bank Indonesia occurred on August 17, 2019, which coincided with the 74th Indonesian Independence Day.

Transactions using QRIS are safe and easy. Buyers only need to scan the QR code that has been provided by the seller. QR code scanning can be done through various PJSP applications, because QRIS launched by Bank Indonesia can be used by various PJSPs.

\section{Results and Discussion}

19 Shinta Maharani, 'Ekonomi Digital: Peluang Dan Tantangan Masa Depan Terhadap Ekonomi Syariah Di Indonesia', Conference on Islamic Studies (CoIS ), 2019, 1-11.

${ }^{20}$ Evelyn Angelita pinondang Manurung and Eka Ayu Purnama Lestari, 'Kajian Perlindungan EPayment Berbasis Qr-Code Dalam E-Commerce', Jurnal Penelitian Dan Pengembangan Sains Dan Humaniora, 4.1 (2020),

<https://doi.org/10.23887/jppsh.v4i1.24323>. 
Analysis of the development of MSMEs in Indonesia

\begin{tabular}{ccc}
\hline Business & $\mathbf{2 0 1 6}$ & $\mathbf{2 0 1 7}$ \\
\hline Micro & $60,863,578$ & $62,106,900$ \\
\hline Small & 731.047 & 757,090 \\
\hline Intermediate & 56.551 & 58,627 \\
\hline Amount & $61,651,176$ & $62,922,617$ \\
\hline Business & $\mathbf{2 0 1 8}$ & $\mathbf{2 0 1 9}$ \\
\hline Micro & $63,350,222$ & $64,601,352$ \\
\hline Small & 783,132 & 798,678 \\
\hline Intermediate & 60,702 & 65,465 \\
\hline Amount & $64,194,056$ & $65,465,496$ \\
\hline Micro, & Small & and $\quad$ Medium
\end{tabular}

Enterprises (MSMEs), are the main key to the Indonesian economy. MSMEs play an important role in improving the Indonesian economy, which is evidenced by the persistence of MSMEs during the pandemic. MSMEs are a strong business sector and have an impact on economic growth in Indonesia. Freezing MSEs has proven to be an economic safeguard when large companies go bankrupt, MSMEs can still survive ${ }^{21}$ MSMEs contribute in providing opportunities or employment, which is $96.99 \%$ in number and contributes to the formation of GDP as much as $60.34 \%$. In addition to these two things, MSMEs also contributed to the addition of foreign exchange in the form of export revenues of 27,700 billion and this created a role of $4.86 \%$ of total exports. ${ }^{22}$. Based on this, it can be said

${ }^{21}$ Supriyanto Nasution, Lily Karlina; Murni, Mayang; Dewi, Ika Sari;, 'THE IMPLEMENTATION OF SAK ETAP AND THE EFFECT OF UMKM PREPARATION IN DEALING WITH MEA (ASEAN ECONOMIC SOCIETY) (CASE STUDY ON UMKM MEDAN \& BINJAI IN 2016)', JOJAPS, 10 (2017), 89.

22 Chalimatus Sya, Debby Silvyarini Fajrin, and Neysa P Febri Anne, 'Pengaruh Kinerja Mitra Binaan (UMKM) Terhadap Pertumbuhan Ekonomi Di Indonesia (Studi Kasus: UMKM Mitra Binaan that MSMEs have an important role in the Indonesian economy.

MSMEs, in addition to having such an important role in the Indonesian economy, the development of MSMEs in Indonesia has increased. Based on data quoted from the official BPS website, data on the development of MSMEs in Indonesia can be seen in the following table. ${ }^{23}$

Table 1. Development of MSMEs in Indonesia for the 2016-2019 period

Source: Data from the Indonesian Ministry of Cooperatives and MSMEs

Based on these data, it can be concluded that the development of MSMEs has increased significantly. The development of MSMEs, seen from before the pandemic, is the beginning of improving the Indonesian economy. In this case, such conditions provide a great opportunity for MSMEs to immediately make adaptations and changes related to the phenomena that occur. So, with the development of MSMEs, MSMEs are not only used as an instrument for improving the economy, but also as an instrument for eradicating poverty in Indonesia ${ }^{24}$.

The rapid development of the number of MSMEs in Indonesia is also followed by the increasing number of workers in Indonesia. In this regard, the following is presented supporting data.

Figure 2. Number of MSMEs and Manpower Absorption in 2015-2019

CSR\&SMEPP Jatim BaliNus MOR V)', ISEI Economic Review, I.1 (2017), 20-25.

${ }^{23}$ Ministry of Cooperatives and SMEs of the Republic of Indonesia, 'MSME Data', Kemenkopukm Web Site, $2021<$ kemenkopukm.go.id $>$.

${ }^{24}$ AL Bara and Riyan Pradesyah, 'Analysis of Restructuring for MSMEs in a Pandemic Period', 2021, 318-22. 


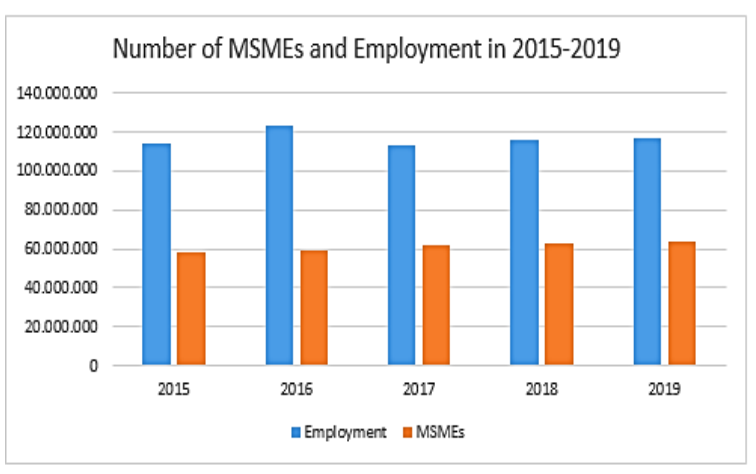

Source: BPS data 2015-2019 of the Independence of the Republic of Indonesia. The existence of QRIS is one of the implementations of the Indonesian Payment System Vision (SPI) 2025 which was previously announced in May 2019. The presence of QRIS as a payment standard is intended so that transaction payments are made through one door, making transactions faster and easier. The target of using QRIS is economic actors. ${ }^{25}$

Transactions using QRIS are fairly

Based on the data in the graph, it can be concluded that the increase in the number of MSMEs is directly proportional to the increase in the workforce. In this case, when there is an increase in the number of existing MSMEs, it will be offset by an increase in the number of workers. In practice, when an MSME is established, it directly requires human resources.

As the pillar of national economic system, MSMEs must be able to adapt to all existing conditions and conditions, one of which is the sudden impact of a pandemic. Thus, MSMEs can survive and be able to become pillars of the economy. However, in reality many MSMEs have not been able to survive due to lack of adaptation. In an effort to revive the existence of MSMEs for economic recovery, the government is in synergy with the Central bank to formulate several policies, one of which is digitalization. The digitalization offered by the Central Bank is in the form of digitizing payments based on QRIS.

\section{The existence of QRIS-based payment Digitalization in MSMEs}

QRIS is a non-cash payment method launched by the Central Bank, namely Bank Indonesia in order to answer the issue of digitizing MSMEs for economic recovery in Indonesia after a prolonged pandemic.

The launch of QRIS by Bank Indonesia coincided with the 74th Anniversary easy. Transactions are carried out only by scanning the QR code owned by the seller through existing non-cash payment applications. In addition, the use of these applications can be done on all types, so it is not limited to certain applications.

How QRIS works can be analogized as follows. Person A has a digital wallet in the form of GoPay, Person B has OVO and Person $\mathrm{C}$ has DANA. All three can make payment transactions by simply scanning the QR code provided by the merchant. In other words, Person A who only has GoPay does not have to scan the same special QR code or does not have to scan the QR code from GoPay. So even if the merchant or shop owner doesn't have GoPay, OVO or others, transactions can still be done.Because the QRIS that was developed has the slogan, "one QR Code for all payments". ${ }^{26}$ The following is an example of the QRIS in question

\section{n.}

Figure 3. Example of QRIS in Rummy Cell

\section{Business}

25 Indra Kurniawan and Hari Sukarno, 'The Shifting Of Qr Code-Based Payment Method To Improve The Competitive Advantage (Ca) At Bank Jatim Through Tam Model Approach', 23.3 (2021), 2227 <https://doi.org/ 10.9790/487X-2303072227>.

${ }^{26}$ PT Telkom Indonesia, 'QRIS', Qris Wb Site, $2020<$ qris.id $>$. 


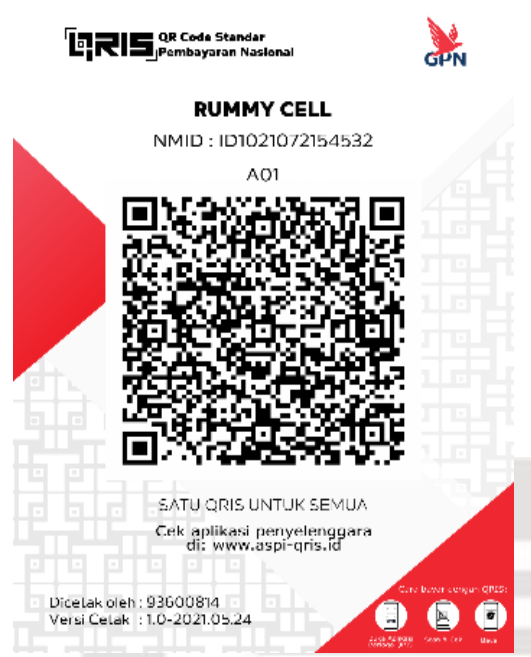

Based on the figure, it can be formulated as follows.

At the top of the left side, there is a logo that reads QRIS QR Code Indonesian Standard. The logo is the identity of QRIS. In addition, the logo includes "National Payments" with the intention of confirming that QRIS is the national non-cash payment standard.

The top on the right side is the GPN logo. The GPN logo or National Payment Gateway is a logo that describes the Indonesian retail payment system which is prepared for progress and healthy competition in national digital transactions.

At the top center there is the name of the merchant used in this example is Rummy Cell. The name of the merchant is the name of the seller, which in this case is the MSME actor.

At the bottom, there is an NMID (ID number) and below it is a TID. The ID number is the identity number of the MSME concerned. Meanwhile, TID is the terminal ID used for receiving transactions.

The middle part is a QR code, which is used as a payment medium. Then at the bottom there is the name of the Acquirer and the printed version.
The urgency of QRIS in realizing payment Digitalization for MSMEs

Bank Indonesia's QRIS has the slogan UNGGUL (UNiversal, GampanG, Untung and Langsung).

Universal, meaning that it can be used by several groups of people. The use of QRIS is not limited to certain groups of people. QRIS can be used by everyone provided that there is a software device that provides the QRIS.

GampanG, meaning that it is easy and safe to use. The use of QRIS is only by scanning the barcode that has been provided, and this process can be done through various digital payment applications. QRIS does not require buyers to have the same digital payment application as sellers, so in this case, the principle of convenience and convenience can be established.

Untung, QRIS provides benefits for both sellers and buyers because of the efficiency of payments and no admin fees. Buyers only need to provide one digital payment application and can immediately make transactions.

Langsung, meaning that transactions with QRIS occur directly, quickly and without hassle. That is only by scanning the provided barcode. In this case, buyers can directly scan without having to take money out of their wallet or calculate or look for the right money.

QRIS is highly recommended for MSME actors, this is because QRIS can help MSMEs adapt to the industrial revolution. QRIS is beneficial for both parties who make transactions, not only limited to the seller's side. The following will describe the benefits obtained from QRIS.

For Merchants (Sellers), QRIS is useful in raising sales, branding, practical, cost-effective and energy, avoiding counterfeit money, and separation of 
business and personal funds and credit profile.

Increased sales. The increase in sales occurred because QRIS-based transactions can be carried out in various existing noncash payment applications.

Branding. Using QRIS as a payment medium can provide value for MSMEs that use it. In this case, MSMEs are more modern and flexible because they are able to adapt to advances in science and technology.

Practical. Transactions using QRIS only require one $\mathrm{QR}$ code. If you have problems with the $\mathrm{QR}$ code, then another alternative can be with the pin provided by the merchant, so this does not complicate the buyer.

Save cost and energy. In the QRIS provider application system offered by Bank Indonesia, there is an automated system for recording incoming and outgoing cash, so that merchants no longer need to spend money and energy in recording their income and expenses. In addition, with this automation, it can avoid recording errors and fraud or fraudulent records.

$$
\text { Avoid counterfeit money. }
$$

Transactions using QRIS do not use physical money at all, so merchants can avoid counterfeit money. In addition, merchants also don't need to bother preparing change, because the system is automatic.

Separation of business and personal funds. In addition to making it easier to record incoming and outgoing cash, QRIS can minimize the mixing of funds between business funds and personal funds. Therefore, traders do not have to worry about losses because small business funds have been used for personal matters.

Credit profile. Transactions with QRIS can build information about credit profiles, which is useful for credit applications.

For Buyers (Users), QRIS is useful such as flexible, practical, and secure.
Flexible. For users of electronic payment applications, QRIS can be accessed through various types of applications so that users do not need to download the same application as a merchant.

Practical. Because it only uses a scan system, it can make payments easier, so you don't have to bother carrying a wallet anymore. Which this can reduce the number of crimes or crimes such as pickpocketing or theft.

Safe. All QRIS provider PJSPs have been officially licensed and even supervised directly by Bank Indonesia as the Central Bank.

There are so many benefits provided by QRIS, so it is not surprising that the Central Bank continues to encourage the transformation of payments into the form of QRIS. To date, there have been 12 million merchants who have switched to QRIS. These figures are subject to change at any time.

QRIS payments are made only by scanning the buyer to the merchant. In this case, there are two types of payments that can be made.

Merchant Presented Mode (MPM) Static. The use of this type, is usually more suitable when used by small-scale businesses.

This mode is done by providing a QR code by the merchant which is then used as a display for the business (print out). Buyers only need to do a scan, then enter the nominal and PIN and then pay.

Dynamic Merchant Presented Mode (MPM). The use of this type is usually more suitable when used by medium and large scale businesses. This mode is done by providing QR through a device, for example an EDC machine or others. Then the merchant enters the nominal amount of the transaction first, which the buyer can then scan. 
The rapid development of life dynamics that increasingly lead to digital, requires economic actors, especially MSMEs in Indonesia to adapt to the circumstances. QRIS became the first and early choice of digital adaptation. In addition, the tradition of Indonesian society is now changing to prefer to transact non-cash. This phenomenon is characterized by the increasing use of noncash transactions through digital wallets or electronic money such as DANA, OVO, GoPay, and so on.

Figure 4. Graph of The Amount of Electronic Money in circulation (Million)

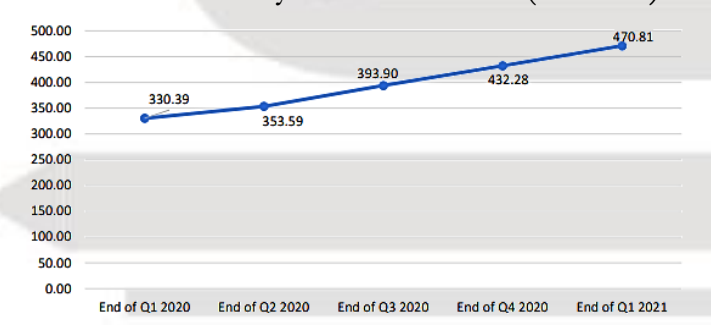

Source: ASPI Statistics News

Based on the graph, the trend of electronic money in Indonesia in every quarter always experienced growth. Numerically, the amount of electronic money in circulation in the first quarter of 2021 reached 470.81 million.

Related to this, it turns out that the trend of using QRIS in the first quarter of 2021 also experienced a significant increase. This is evidenced by the following graphic image.

Figure 5: QRIS transaction volume graph (Millions)

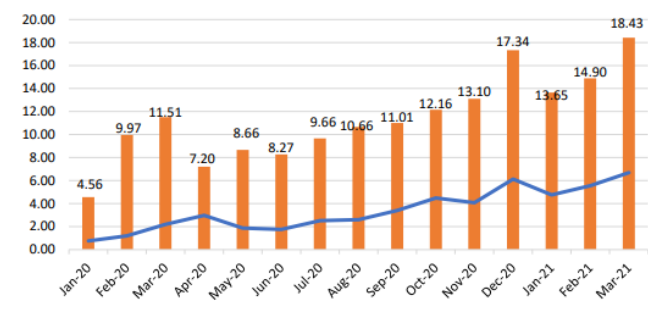

\section{Source: ASPI Statistics News}

The graph shows, the bar diagram shows the total growth of QRIS - volume, while the line diagram, shows the volume of Off-Us transactions. In the graph, in 2020 to the first quarter of 2021 the pace of movement is fluctuating, but it can be seen that in the first quarter of 2021 precisely in January to March, transactions using QRIS increased.

Based on these two graphs, MSMEs can begin to adapt by transforming from manual to digital, so that later MSMEs can survive, especially in this pandemic period. QRIS is the new beginning of Indonesia's economic recovery and the new face of MSMEs in Indonesia.

\section{Conclusion}

MSMEs are a pillar of the Indonesian economy. Today, the development of MSMEs occurs rapidly. The rapid development of MSMEs should be marked by a great opportunity for the recovery of the Indonesian economy during the pandemic. However, it seems that this cannot be realized, because many MSMEs have collapsed due to the pandemic. The failure of MSMEs is due to the inability of MSMEs to adapt to existing conditions. As an effort to solve this problem, Bank Indonesia and the government have formulated a series of policies, one of which is the acceleration of Digitalization. The acceleration of Digitalization that is being driven is primarily directed at MSME actors in order to form an MSME Digitalization ecosystem. The concept of digitizing MSMEs offered by Bank Indonesia is in the form of digitizing payments based on QRIS (Quick Response Indonesian Standard).SUPERIOR(UNiversal, Easy, Profit and Direct). The use of QRIS is only in the form of scanning a QR code by 
the buyer using any PJSP application. The ease of using QRIS is beneficial for both buyers and merchants. For merchants, QRIS is useful in terms of increasing sales, practicality, branding, saving, avoiding counterfeit money, segregating business funds, and credit profiles. For users, the benefits of QRIS are flexible, safe and practical. With the various facilities provided, it can be said that QRIS is a driver of accelerating digitalization for economic recovery.

\section{Bibliography}

Journal

Akbar, Ricky, Meza Silvana, and Fikiri Aulia Alizar, 'Designing a Non-Cash Payment Application for Car Wash Business Management Using QR Code Technology (Case Study: Oto Pro Car Wash \& Detailing Padang)', National Seminar on Science and Technology, 1.1 ( 2019), 1-13 $<$ jurnal.umj.ac.id/index.php/semnast $\mathrm{ek}>$
Restructuring for MSMEs in a Pandemic Period', 2021, 318-22

Business, Journal of Management, '(1) (2) (3)', 17.2 (2020), 287-97

Blandina, Selena Riri, Alvin Noor Fitrian, and Wulan Septiyani, 'Strategies to Avoid Indonesia from the Threat of an Economic Recession During a Pandemic', Effector, 7.2 (2020), 181-90

Cakrawati, Jurnal, and I Ketut Kasna, 'Guarding Economic Recovery After the Pandemic', 04.02 (2022), 103-13

Fahrika, A Ika, and Juliansyah Roy, 'The Impact of the Covid-19 Pandemic on Macroeconomic Developments in Indonesia and Policy Responses Taken The Impact of the Covid-19 Pandemic on Macroeconomic Developments in Indonesia and The Policy Response Taken', Innovation, 16.2 (2020), 206-13

Alfarizi, Muhammad, Rastinia Kamila Hanum, and Syaibatul Aslamiyah Hidayat, 'Optimizing the Use of Sharia Digital Transactions To SupPort Indonesia' S Economic Recovery', 6.1 (2021), 122-32 $<$ https://doi.org/10.20473 /jiet.v6.11.25977>

Arifqi, Moh. Musfiq, 'Indonesia's Economic Recovery Through Digitizing Sharia-Based MSMEs During the Covid-19 Pandemic', Al-Kharaj: Islamic Journal of Economics, Finance \& Business, 3.2 (2021), 192-205

$<$ https://doi.org/10.47467/ alkharaj.v3i2.311>

Bara, AL, and Riyan Pradesyah, 'Analysis of
Irawan, Agustinus Purna, Hetty Karunia Tunjungsari, Paula Tjatoerwidya Anggarina, and Nicholas Rijako, 'The Role of Higher Education in Improving Micro, Small, and Medium Enterprises' Performance; A Case Study: Untar For MSMEs', Proceedings of the International Conference on Economics, Business, Social, and Humanities (ICEBSH 2021), 570.ICEBSH (2021), 1417-20 $<$ https://doi.org/10.2991/assehr .k.210805.222>

Kurniawan, Indra, and Hari Sukarno, 'The Shifting Of Qr Code-Based Payment Method To Improve The Competitive Advantage ( $\mathrm{Ca}$ ) At Bank Jatim Through Tam 
Model Approach', 23.3 (2021), 22-27 <https://doi. org/10.9790/487X-2303072227>

Maharani, Shinta, 'Digital Economy: Future Opportunities And Challenges Towards Islamic Economy In Indonesia', Conference on Islamic Studies (CoIS ), 2019, 1-11 $<$ http://lppmunissula.com/jurnal.unissula.ac. en/index.php/cois/article/downl oad/7981/3634>

Manurung, Evelyn Angelita pinondang, and Eka Ayu Purnama Lestari, 'Study of Qr-Code-Based E-Payment Protection in E-Commerce', Journal of Research and Development of Science and Humanities, 4.1 (2020), 28 $<$ https://doi.org /10.23887/jppsh.v4i1.24323>

Nalini, Siti Nuzul Laila, 'The Impact of Covid-19 on Micro, Small and Medium Enterprises', Jesya (Journal of Sharia Economics \& Economics), 4.1 (2021), 662-69 $<$ https://doi.org/10.36778/jesya $. v 4 \mathrm{i} 1.278>$

Nastiti, Dwiny Indah, Sitti Nur, Azmi Fadhlurrahmah, and Nurul Hermina, 'The Impacts Of Macro Environment And Consumer Behavior On Performance Improvement Through Marketing Program ( Case Study On The Use Of Digital Payment By Sms Syvastem In Qris, Indonesia ', 32.3 (2021), 8963-83

Nasution, Lily Karlina; Pure, Mayang; Dewi, Ika Sari;, Supriyanto, 'The Implementation Of Sak Etap And The Effect Of Msme Preparation
In Dealing With Mea (Asean Economic Society) (Case Study On Medan \& Binjai In 2016)', JOJAPS, 10 (2017), 89

Permadi, Yudistira Andi, and Angestika Wilandari, 'Preferences of Using Quick Response Code Indonesian Standard (QRIS) Among Students as a Means of Digital Payment', 03.01 (2021)

Prehanto, Adi, Rangga Degree Guntara, and Nuraly Masum Aprily, 'Utilizing Webinars as Alternatives to Digitizing Information in Curriculum Seminars', Indonesian Journal of Digital Business, 1.1 May 2021 (2021), 42-48 $<$ https:/ / ejournal.upi. edu/index.php/IJDB/article/vie $\mathrm{w} / 34356>$

Putri, Retno Karunia, Rahmawati Indah Sari, Rita Wahyuningsih, and Ety Meikhati, 'The Phk Rate Against Decline', 1.1 (2020), 50-55

Putro, Suryati Eko, and Novie Noordiana, 'Development of Micro, Small and Medium Enterprises (MSMEs) in the Context of Economic Empowerment in the New Normal Era', Journal of Community Service, 1.2 (2021), 6572

Rizkyka Choirunnisa and Egi Arvian Firmansyah, 'Muslim Consumer Behavior and Purchase', EKONOMIKA SYARIAH: Journal of Economic Studies, 5.1 (2021), 11-30

Saputri, Oktoviana Banda, 'Consumer Preferences in Using the Quick Response Code Indonesia Standard (QRIS) as a Digital Payment Tool', Journals of Economics and Business Mulawarman, 17.2 (2020), 237-47 
Setiyono, Taufiq Andre, 'Indonesian's Acceptance of Non-Cash

Transaction Using Qris',

Proceedings of the 3rd

International Conference on

Banking, Accounting,

Management and Economics

(ICOBAME 2020), 169.Icobame

2020 (2021), 141-44 <https:

//doi.org/10.2991/aebmr.k.2103

11.027>

Simamora, Caterin Magdalena, and Rahayu Ningsih, 'Inclusivity of the Digital Economy in Indonesia: Gender Perspectives and Job Creation.', Cendekia Niaga, 4.2 (2020), 39-53 $<$ https://doi.org/10.52391/jen. v4i2 .507>

Sya, Chalimatus, Debby Silvyarini Fajrin, and Neysa P Febri Anne, 'The Influence of the Performance of Foster Partners (MSMEs) on Economic Growth in Indonesia (Case Study: MSME Partners CSR\&SMEPP East Java BaliNus MOR V)', ISEI Economic Review, I.1 ( 2017), 20-25 http://jurnal.iseibandung.or.id/i ndex.php/ier

Website

Indonesia, Bank, 'QR Code Indonesian Standard (QRIS)', Www.Bi.Go.Id, 2021 $<$ https://www.bi.go.id/QRIS/d efault.aspx $>$

Indonesia, Ministry of Cooperatives and SMEs Republic, 'SME Data', Kemenkopukm Web Site, 2021 $<$ kemenkopukm.go.id $>$

Indonesia, PT Telkom, 'QRIS', Qris Wb Site, $2020<$ qris.id $>$ 